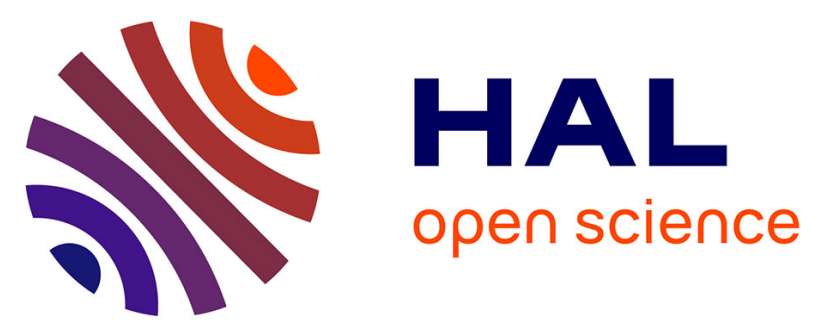

\title{
Armand Hatchuel and the Refoundation of Management Research: Design Theory and the Epistemology of Collective Action
}

\author{
Blanche Segrestin, Franck Aggeri, Albert David, Pascal Le Masson
}

\section{To cite this version:}

Blanche Segrestin, Franck Aggeri, Albert David, Pascal Le Masson. Armand Hatchuel and the Refoundation of Management Research: Design Theory and the Epistemology of Collective Action. David B. Szabla, William A. Pasmore, Mary A. Barnes, Asha N. Gipson. The Palgrave Handbook of Organizational Change Thinkers, 22, Springer, pp.1-15, 2017, 978-3-319-49820-1. 10.1007/978-3-31949820-1_80-1 . hal-01516296

HAL Id: hal-01516296

https://hal-mines-paristech.archives-ouvertes.fr/hal-01516296

Submitted on 5 Mar 2018

HAL is a multi-disciplinary open access archive for the deposit and dissemination of scientific research documents, whether they are published or not. The documents may come from teaching and research institutions in France or abroad, or from public or private research centers.
L'archive ouverte pluridisciplinaire HAL, est destinée au dépôt et à la diffusion de documents scientifiques de niveau recherche, publiés ou non, émanant des établissements d'enseignement et de recherche français ou étrangers, des laboratoires publics ou privés. 


\title{
Armand Hatchuel and the Refoundation of Management Research: Design Theory and the Epistemology of Collective Action
}

\author{
Blanche Segrestin, Franck Aggeri, Albert David, and \\ Pascal Le Masson
}

\begin{abstract}
Armand Hatchuel's work marks a turning point in management research and paves the way for a refoundation of management science. Hatchuel's research deals with organizational metabolism rather than organizational change, as he is concerned with the drivers of change and with the organization of innovative collective action. Several theoretical milestones can be put forward. First, Hatchuel offers a theory of the cognitive processes of generativity: while decision theory targets optimization by supporting the selection of a solution, " $\mathrm{C}-\mathrm{K}$ theory" is a design theory. It accounts for the generation of new alternatives by expanding what is known, this process being driven by desirable unknowns. This theory has provided the theoretical cornerstone characterizing the rationality and organization of innovative or design-oriented collective action. Second, in Hatchuel's view, learning and organizational dynamics are tightly bound. Learning processes are hosted and supported by social relationships, which, in turn, are shaped by the distribution of knowledge. Hatchuel proposes a theory of collective action whereby knowledge and relationships are involved in a dynamic interplay: this theory shows that both markets and hierarchies are special and highly unstable forms of organization, because they imply that either knowledge or relationships are frozen. Management scholars contribute to the study of generative forms of collective action: Hatchuel argues that management science, far from being applied economics or applied sociology, is a basic science devoted to
\end{abstract}

B. Segrestin $(\bowtie) \cdot$ F. Aggeri $\bullet$ P. Le Masson

MINES ParisTech, PSL Research University, CGS -Centre de gestion scientifique, i3 UMR CNRS 9217, Paris, France

e-mail: blanche.segrestin@mines-paristech.fr; franck.aggeri@mines-paristech.fr; lemasson@mines-paristech.fr

A. David

M-Lab, Dauphine Université, PSL Research University, Paris, France

e-mail: albert.david@dauphine.fr 
the design and study of new models of collective action. He therefore opens up promising avenues for programs on post-decision paradigms and creative institutions.

\section{Keywords}

Collective action $\bullet$ Management sciences $\bullet$ Innovation $\bullet$ Innovation management $\bullet$ Design theory $\bullet$ Generativity

\section{Contents}

Influences and Motivations: Beyond Management as Optimization (Capturing the Hidden Trajectories of Rationalization Waves Through Intervention Research) ................. 2 Key Contributions: Integrating Organizational and Technical Changes: Expandable Rationality and Generative Collective Action

Organization and Knowledge as Interrelated Dynamics: Multiple Forms of Expertise

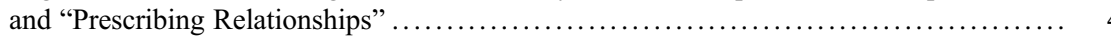

Beyond Bounded Rationality and Decision Theory: Expandable Rationality and a New

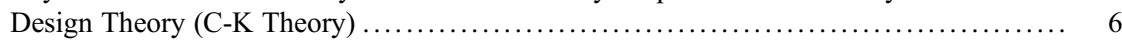

New Foundations for a Theory of Collective Action: The Knowledge/Relationships

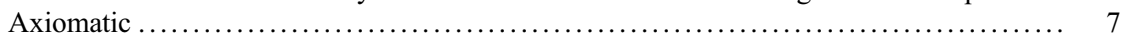

New Insights: Management Science as a Basic Science ............................ 9

Legacies and Ongoing Programs: Toward a Theory of Creative Rationalities and

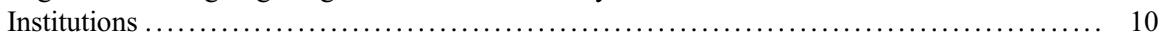

A Post-Decisional Paradigm of Collective Action .............................. 10

A Theory of the Firm as a Locus of Collective Creation ......................... 11

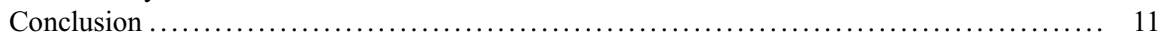

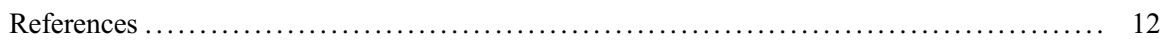

\section{Influences and Motivations: Beyond Management as Optimization (Capturing the Hidden Trajectories of Rationalization Waves Through Intervention Research)}

Armand Hatchuel's work marks a turning point in management research, with his theory of creative and responsible collective action. A full professor at MINES ParisTech, he has been the scientific director of the Center for Management Science since the 1980s. He is also a fellow of the Design Society and a member of the French Academy of Technology. He began his research at Ecole des Mines in 1973 in the newly created Center for Management Research. In the 1980s, he benefited from the French intellectual landscape and from debates about management research. The National Foundation for Management Education played a major role by supporting annual workshops on epistemological issues where doctoral students and senior researchers could meet to discuss the epistemology and academic identity of management science (Moisdon 1984; Martinet 1990). They addressed questions such as: What is the object of management research? Why is it different from older established disciplines like economics or sociology? What is a managerial situation? Is management science a social science? Or an engineering science? Hatchuel was 
eventually able to make landmark contributions to these debates by elaborating a new foundational perspective on management (Hatchuel 2001a).

Drawing on his background in engineering, he started working on operations research $(\mathrm{OR})$ and its industrial applications. Later, the general concepts of instrumentation, rationalization, or formalization of collective change were always central to his research. However, Hatchuel draws on diverse fields and disciplines, from mathematics (see, for instance, Hatchuel 2008; Hatchuel et al. 2013) to philosophy, via arts (cf. his admiration for Duchamp) or rhetoric (Hatchuel 2006, 2013). His research involves extremely in-depth empirical studies. For instance, Hatchuel has led longitudinal studies on a metalworking company, on public transport, and later on industrial design offices and research units. But his research also focuses on mega-transformations of organizations or what Hatchuel called "waves of rationalization" (Hatchuel and Weil 1995; see also Hatchuel's historical view of the firm through an analysis of the successive forms of management: Hatchuel 2004).

In this diversity of references and methods, there are some clear unifying concerns in Hatchuel's research. First, in our view, Hatchuel has always focused on new phenomena that push our theoretical frameworks to their limits and call both for new ways of observing them and for renewed theories. He has always advised younger scholars to study what was not covered by existing theories, either new practices or phenomena, or problems that revealed that the theories were no longer matching the empirical facts (Hatchuel 2001c; Hatchuel and David 2007). In this sense, quantum mechanics has always been a fundamental reference point for Hatchuel because to capture an unobservable phenomenon, a researcher needs to develop new ways to describe it, to interact with it, and to discuss its theoretical implications. To be able to capture what is new and unable to be described within traditional frameworks, Hatchuel willingly calls up various fields of science and models, including mathematics and physics, of course, but also law and psychology, to make visible some generic templates or relational schemas that need to be either complemented or contradicted.

Second, and perhaps more critically, the governing principle in Hatchuel's research has been to study not the new phenomena themselves but rather the mechanisms that generated them. For instance, OR interested him as an example of the process of "rational modeling" that underlies any organizational change (Hatchuel and Molet 1986). This also explains why Hatchuel has followed "waves of rationalization" (Hatchuel and Weil 1995) throughout his career. From manufacturing systems to design offices and "design-oriented organizations" (Hatchuel and Weil 1999; Hatchuel et al. 2006), he was tracking not only new words or new organizations but also the transformative drivers behind them. In this respect, he has paid thorough attention to the way in which new pieces of knowledge can transform social relationships and also to how relationships condition the possibility of knowledge creation. Here, the influence of the philosophy of Michel Foucault should be emphasized (Hatchuel 1999b). As a management scholar, Hatchuel took Foucault's thoughts one step further (Hatchuel et al. 2005): how could these drivers be created and amplified, that is to say, organized? These 
questions may explain the attachment that Hatchuel has with some institutions, such as Ecole des Mines and the Cultural Center of Cerisy la Salle. Ecole des Mines (today MINES ParisTech - PSL Research University) is one of the oldest institutions for engineering research and education, and it is clearly no mere coincidence that Hatchuel's research takes place in an environment of engineering sciences: engineers develop what he called "actionable" knowledge or knowledge for the sake of collective action. More particularly, compared with researchers, engineers not only model observable phenomena but also tend to generate new phenomena (e.g., the electric car, 3D printing, and antibiotics without resistance). As a result, these phenomena can invalidate existing theories and call for renewed ones. As for Cerisy's International Cultural Center, many "colloques de Cerisy" (1 week of intensive meetings) have punctuated the intellectual path of Hatchuel. This is a symbolic place where researchers, public actors, and industrial practitioners have met for more than a century to undertake collective intensive reflection and develop genuinely new thoughts in an interdisciplinary and truly progressive way (Hatchuel 2011).

\section{Key Contributions: Integrating Organizational and Technical Changes: Expandable Rationality and Generative Collective Action}

While he has definitely contributed to the field of organizational change, Hatchuel has also coined broader terms to characterize various research issues. For instance, instead of organizational change, he refers to the "metabolism" of the organization, which he defines as the factors that enable an organization to renew itself. Here, the term "metabolism" does not refer to a kind of natural transformation. Hatchuel uses it to point to the mechanisms that drive the change more than to the change itself, be it planned or emergent. He is indeed more interested in the "organizing of the change," i.e., the activities that lead to the possibility of change, including the extension of the range of conceivable changes and the definition of its objectives, scope, and actors.

Here, we do not pretend to cover all the work Hatchuel has done or influenced. On the contrary, we deliberately focus on three major contributions, namely, the modeling of prescribing relationships as the core of the organizing action, the modeling of post-decisional logic with the $\mathrm{C}-\mathrm{K}$ theory, and the theorization of collective action.

\section{Organization and Knowledge as Interrelated Dynamics: Multiple Forms of Expertise and "Prescribing Relationships"}

Organizational change, especially in its rationalized form, is classically associated with a conscious attempt to modify an organization in accordance with some form of expertise and preestablished models. However, it is clear that no change happens without learning processes. Even the implementation of a technique, be it managerial 
(e.g., planning, kanban, or a roadmap) or otherwise, implies that some knowledge must be learnt and then implemented collectively in a certain way. The dynamics of organizational learning have proved to be decisive in any organizational change. Working on the way in which OR can change an organization, Hatchuel observed that the final state of the change was itself a matter of learning: rational models of OR were conceived as "rational myths," i.e., formalizations, within a given state of knowledge, of the possible desirable organizational forms, and as a way to engage a reflective learning process within the organization (Hatchuel and Molet 1986).

To gain a thorough understanding of the way in which knowledge was produced and used in concrete organizational settings, Hatchuel analyzed the role of experts in organizations. For instance, he studied in a reflective way the intervention processes of management scholars. In the 1990s, in conjunction with Weil, he studied experts extensively, focusing on expert systems in organizations. Together, they modeled the nature of expertise in connection with the actions it enables (Hatchuel and Weil 1995). They showed that the way knowledge was produced conditioned its possible uses and that the coordination of learning dynamics appears to be critical in the act of organizing. This approach served to denaturalize organizations. An organization necessarily results from a genealogical process, wherein the structures and organizational relationships shape the learning processes, but they are reciprocally transformed by the knowledge that is produced.

In this way, Hatchuel invites us to consider not only the organizational change itself but also the "organizational metabolism" through the interplay between knowledge and relationships. For instance, instead of focusing on job division, we need to account for learning division, because the ways in which knowledge is produced necessarily shapes the definition of the jobs itself. First and foremost, organizing involves defining the appropriate conditions for learning processes. It could be said that Hatchuel has moved beyond the field of organization theory to usher in a new theory regarding of changing processes or organizing itself.

This led Hatchuel to revisit the legacy of F.W. Taylor and offer a completely new reading of Taylor's contribution to organizational theories (Hatchuel 1994, 1995, 1996, 1997, 1999a, 2004; Hatchuel and Ponssard 1996). Taylorism is often seen as the distinction between conception and execution of workflows, but Hatchuel observed that this interpretation neglects the diversity of knowledge required in modern organizations and the conditions necessary to produce it. On the contrary, Taylor recognized that independent workers could not develop the tools and methods required to manufacture more complex and changing products. The organization needed people to specialize in the production of these new products and methods. This explained the birth of a new category of actors (namely, the planning department) as well as a new epistemic community, which would later lead to scientific management and more broadly to the field of management science.

Hatchuel introduced the key notion of "prescribing relationships," without which it is impossible to understand organizational dynamics. The term "prescription" refers to the notion of recommendation by an expert, typically a physician. Hatchuel uses it to designate all statements that impact the knowledge, actions, and judgment of other people, while being neither orders nor hierarchical commandments 
(Hatchuel 1998). This takes into account prescriptions that may be imprecise, "weak," or "open", as well as reciprocal prescriptions.

This was a drastic turnaround. Not only does the notion of "prescribing relationships" shed new light on Taylorism, but it also revisits the classic notions of markets and hierarchies, which appear as extreme cases. Although they are oversimplified constructs, both markets and hierarchies imply that their members share knowledge about both the role of each stakeholder and what they do together or exchange. This can happen in extreme configurations, but in general, knowledge is always missing, e.g., knowledge about the functionality of a product or its quality or knowledge about stakeholders and their respective roles. To work effectively, both markets and hierarchies need prescribing relationships.

In Hatchuel's research, the notion of prescribing relationships was decisive because it provided a key to interpreting the crisis of industrial organizations in the 1990s. The more intensive the regime of innovation became, the more complex but also unstable and fragile prescriptions appeared. It became necessary to study the possibility of organizing prescriptions in the unknown.

\section{Beyond Bounded Rationality and Decision Theory: Expandable Rationality and a New Design Theory (C-K Theory)}

In the 1990s, a whole series of new organizations emerged designed for innovation. The literature introduced new notions such as new product development, project management, absorptive capacity, and alliances. Clearly, organizations needed to change to be able to innovate in a more systematic but also a more disruptive way. In our view, Hatchuel's team took a radical step forward by suggesting that organization theory first supposes a theory of the ways of reasoning and that these ways of reasoning could themselves be managed and made more innovative.

A posteriori, we can understand the scientific path that led to that breakthrough. In a situation of intensive innovation, very few prescriptions are stable and robust: the designers have to develop a product, despite the fact that they know very little, or nothing, about the demands of consumers, the possible technologies, and the business models that are available. Under these conditions, the various models provided by the literature are insufficient: they still address situations where designers have prescriptions and need to improve their products and processes to better fulfill the requirements. But what if the requirements are no longer known? How should the learning processes be organized when the required knowledge has not yet been identified?

Hatchuel and Le Masson showed that research activity organizes a specific type of learning process, namely, one aimed at maximizing the controllability of the knowledge produced (Hatchuel et al. 2001). However, other types of learning processes are possible. How should we characterize a process whose aim is to identify what knowledge is missing or which learning process is needed? Beyond organization theory, what 
was at stake was decision theory. Hatchuel criticized the "unfinished" program of Herbert Simon (Hatchuel 2001b), because Simon still saw design through the lense of "problem solving." However, knowledge is not necessarily produced to solve a problem; it can be produced with the ultimate goal of opening up new and unexpected perspectives. For Hatchuel, these open-ended learning processes need to be understood and organized if we are to speak about innovation management. The design theory developed by Hatchuel and Weil expands upon decision theory (Hatchuel and Weil 2002, 2009): it models the reasoning process that, instead of selecting a solution from among a given set of solutions (regardless of how large and ill-defined the set is), allows for the expansion of the set of solutions. To do that, they show that it is necessary to introduce "undecidable propositions": a design task does not start with a "problem" but with an unknown, i.e., an undecidable proposition (for instance, "a computer with no energy" or a "magic light"), which can be neither validated nor invalidated using existing knowledge.

The design theory developed by Hatchuel, Weil, and Le Masson is called the " $\mathrm{C}$ $\mathrm{K}$ theory." This is a formal model of the generative reasoning that building upon set theory accounts for the creation of new objects. Starting from an unknown, referred to as a "concept," the C-K theory accounts for the dual transformation of the knowledge $(\mathrm{K})$ space (where the concept stimulates new learning processes) and the concept (C) space (where knowledge leads to the specification of the properties of the concepts). The creative process is a result of this dual expansion. The authors claim that the C-K theory is not only an interpretative framework for generative processes but enables innovation, as the formalism reveals, to be structured and controlled in a rigorous way.

It is beyond the scope of this chapter to discuss the implications of C-K theory in detail, but it has led to a series of important results in relation to organizational change. Several of the theoretical methods used to evaluate the innovative capacities of either projects or organizations have been developed using C-K theory. The KCP (Knowledge-Concept-Proposals) method has also been derived from C-K theory to support creative processes involving numerous heterogeneous participants. Today, our understanding of generative logic has opened up many perspectives on the analysis and conduct of change in various organizational contexts (e.g., firms or ecosystems).

\section{New Foundations for a Theory of Collective Action: The Knowledge/ Relationships Axiomatic}

The third, but probably most significant contribution of Hatchuel to the field of organizational change, is his theory of collective action. Hatchuel argues that collective action can and must be designed, because neither its goals nor its forms are known a priori. Hatchuel has always paid close attention to avoiding this fallacy, which consists of considering things/circumstances as given. This is especially true 
for the enterprise, as it is neither a natural social phenomenon nor an anthropological fact. The enterprise is probably one the most "artefactual" forms of collective action, because it constantly redefines what it does and how it does it (Hatchuel 2001a). Because it is the locus of designed collective action, the enterprise is (or could be?) the very transformational place in our society.

Collective action is hardly describable in the classical language of the social sciences. As soon as one wants to institute unprecedented forms of action, new language also needs to be deployed. A collective action has the specific property that it cannot be realized unless a model has previously been formulated. Probably the simplest example of collective action is a meeting. For a meeting to take place, the parties have to agree on what is an appointment, using related maps and clocks. Similarly, when we refer to companies, joint ventures, and matrix organizations, we always refer to designed models of action. A company cannot innovate without formalizing how it can explore unknown spaces. For instance, it cannot develop a new eco-friendly range of products without formulating not only the properties of the products themselves but also a way to explore these properties and their feasibility. Obviously, innovative collective action cannot occur without new models of collective action.

This perspective has had a great impact on organizational change because instead of focusing on the organization, Hatchuel focuses on the coordination of the learning processes. Instead of adopting a contingency perspective, he speaks of the genealogy of collective entities. Instead of considering the rationality of a change, he invites us to think in terms of rationalization to emphasize the possibility of generating new rationality frames. Finally, instead of assessing a company's performance, he suggests that we study the epistemology within which its performance criteria have possibly emerged (Hatchuel 2001a).

Hatchuel's formulation of an axiomatic theory of collective action (Hatchuel 2001a) is both generic and ambitious. Combining his former work on rational modeling and prescribing relationships, he rejects what he calls the "metaphysics" of action that reduce the total forms of possible action to a unique principle (e.g., utilitarianism). Collective action must be studied to the extent that it transforms relationships and utility functions. The only invariant in the theory of collective action lies in what Hatchuel calls "a principle of inseparability between knowledge and relationships" ("Le principe fondamental d'une théorie de l'action collective est l'inséparabilité des savoirs et des relations") (Hatchuel 2001a, p. 28). This principle refuses to consider that knowledge is independent of relationships. It also refuses (and this may be more original) to view relationships as independent of the knowledge and the organization of learning processes in which they take place (Hatchuel 2005, 2007). This gives a theory based on what Hatchuel coined in French "l'axiomatique savoirs/relations" (the knowledge/ relationships axiomatic). This focus on collective action as a matter of design and organization is central, because it paves the way for new definitions of management and management science. 


\section{New Insights: Management Science as a Basic Science}

For Hatchuel, the purpose of management lies in the design of models of collective action. Management science "is a basic field of research devoted to the study and design of theories, models and tools of collective action" (Hatchuel 2002, 2005). As Hatchuel and David noted, "Likewise, physics is not the study of "reality," but the study and revision of physical models. Consequently, the dialectics between established management theory-in-use and contextual management theory-in-use can be assessed as an important main driver of management theory and history" (Hatchuel and David 2007). This offers a new perspective on management science: instead of viewing management as lying at the crossroads of economics, law, and sociology, Hatchuel contends that management has a distinctive objective in the modeling and design of new models of collective action. In this way, he also makes some rather radical criticisms of economics and sociology. In his view, economics and sociology have been built on restrictive forms of collective action. Having assumed several behavioral models of economic actors, economists have stabilized an underlying utility function, and in so doing, they have become blind to the possibility that collective action transforms utility functions. Similarly, sociologists often posit various special forms of relationship or social status, thereby preventing themselves from conceptualizing how new actors appear or how new forms of relationships are built. However, both history and practice offer numerous examples in which efficiency criteria, as well as societal values, are substantially modified.

In a famous article referred to in France as laying the groundwork for a "foundationist perspective" for management science (Hatchuel 2001a), Hatchuel called for a revised view of the management sciences, arguing that:

management sciences are neither applied economics or sociology, nor a project for educating future managers with a series of practical tools (accounting, marking, strategy...). Management sciences are better characterized by the need of our contemporary society to make emerging forms of collective actions more intelligible and to allow the design of unprecedented organizations. (our translation, Hatchuel 2001a)

Retrospectively, Hatchuel has found that the management science project was probably at the core of the work of the famous pioneers of management. Building upon classical as well as forgotten seminal texts of Fayol (1917, 1918), Hatchuel recently offered a new interpretation of Fayol. A chief executive, natural scientist, and organization theorist, Fayol was a particularly innovative manager who actively supported a scientific approach and achieved major industrial success. Hatchuel showed that Fayol had a visionary understanding of management. In the late nineteenth century, he was confronted by a surge in scientific research in industry. In this context, businesses called for a new function, which Fayol conceptualized as the administrative function. The mission of this business administration function was to organize a controlled and responsible venture into the unknown. It was to hold the organization together despite the unknown it generated by its exploratory action 
(Hatchuel 2016). Hatchuel showed that Fayol had pioneered subsequent research on "creative" organizations, dynamic capabilities, and alternative rationalities based on design and discovery. With this historical detour, Hatchuel once again offered new insights in relation to integrating the dynamics of change and innovation into the foundations of management theory.

\section{Legacies and Ongoing Programs: Toward a Theory of Creative Rationalities and Institutions}

Among the various impacts of Hatchuel's research are several ongoing programs in which the authors are participating in conjunction with Hatchuel.

\section{A Post-Decisional Paradigm of Collective Action}

A program has been launched on design theory, with the support of a number of industrial partners: the Chair "Design theory and Methods for Innovation." This program explores the so-called post-decisional paradigm, i.e., forms of collective action that are unable to be modeled using classical decision-making models (such as problem solving, optimization, and planning) because the level of unknowns and the generativity of action play a critical role (e.g., innovation management and creation in art or science). This follows Hatchuel's research logic: first, explore the models of thought and rationality, and then, relying on these models, explore and model all facets of collective action. In this program, the models of rationality are derived from design theory. In recent years, these works have contributed to the development of a basic science of design theory, which is comparable in terms of its structure, foundations and impact to decision theory, optimization, and game theory. They have reconstructed the historical roots and evolution of design theory, unified the field at a high level of generality, and uncovered theoretical foundations, in particular the logic of generativity, in "design-oriented" structures.

These results have contributed to a paradigm shift in relation to the organization of R\&D departments, supporting the development of new methods and processes in innovation centers. They are also at the root of many works on innovative organizations (see Agogué and Kazakçi 2014) and have helped to better characterize their logic and performance. Following the paradigmatic pattern of decision theory, which articulates models of decision theory with experimental study of decision-making behavior, design theory was also discussed from a cognitive perspective: just as decision theory helped to diagnose individual and group behaviors that depart from decision-making models, design theory helps to conduct "theory-driven experiments" on biases in the ideation process and helps to diagnose fixations in individuals, groups, or professions (e.g., Agogué et al. 2014). The program also studies the so-called design regimes at the level of industrial ecosystems, identifying new forms of lock-in based on collective fixations or, conversely, describing forms of "unlocking rules" and generative institutions, i.e., situations where the institutional 
logic does not impede but rather supports a collective venture into the unknown (Le Masson et al. 2012). It also helps to provide firm ground for a critical perspective on creation and design.

\section{A Theory of the Firm as a Locus of Collective Creation}

A second program focuses on the theory of enterprise, which mainly proposes that modern companies with professional management emerged at the end of the nineteenth century because of the need to organize the development of new collective capabilities (technologies, functions, methods, competencies) that would not otherwise be available. This breakthrough in relation to the history of collective action has deeply transformed our societies. However, despite the tremendous expansion of companies throughout the twentieth century, this process has not been sufficiently conceptualized and has continued to be overlooked, both by the economic theories of the firm and by corporate law.

This has led Hatchuel and Segrestin to explore within an interdisciplinary project at College des Bernardins a new theory of the firm and to question the existing models of corporate governance and corporate law. The transaction cost approach views the firm as a means of reducing transaction costs and controlling opportunism. However, the alternative perspective developed by Hatchuel and Segrestin builds upon the historical development of management as a distinctive function. It conceptualizes the enterprise as an entity dedicated to collective creation as opposed to production. In other words, this perspective views the firm as a means of creating the potential for action that does not currently exist and for which there is not yet a market (Segrestin and Hatchuel 2012). In doing so, they build on the stakeholder theory of the firm, which emphasizes that there is great interdependence among firms as a result of co-specialized investment. However, they go beyond the stakeholder theory of the firm by offering a very specific conceptualization of the role of management as the key to developing the collective competence of the firm in pursuit of an innovative strategy. Then, considering that the law of (public) corporations was already established prior to the birth of modern management, they question the implications of this gap and investigate possible management-based (or innovation-driven) principles of governance, such as mission-driven corporations (Levillain et al. 2014; Segrestin and Hatchuel 2011).

\section{Conclusion}

Beyond these programs, it is worth noting more generally the opening up of the field of epistemology by Hatchuel. By focusing on collective action, Hatchuel often combines traditionally distant academic fields, for example, innovation management and design theory are combined with business history and law. However, more fundamentally, his work questions the constituent hypotheses of disciplines such as economics and sociology because they often posit given models of action. A good 
example is the field of law, which management scholars have often considered to be a given starting point when studying forms of collective action. However, law, like other managerial tools, merely formalizes historical and contextual models of responsible action. Modeling the renewal dynamics of collective action necessarily leads to a change in perspective: instead of considering law as a starting point, management science needs to provide lawyers and scholars in law with new models of action, including generative ones.

To conclude, following Hatchuel, we can only speculate on the future of management science. Do we need to reorder the discipline, similar to what happened in relation to physics at the end of the nineteenth century? Or, rather, should we consider that the key impacts of Hatchuel's work also relate to other fields and that the notions he has shaped are useful for various disciplines? Hatchuel has searched for solid and rigorous foundations for management science with such deep theoretical bases that they likely constitute a common ground for the social sciences and perhaps even more distant fields. Maybe it is the mark of genuinely critical research that it springs from within a single discipline but is eventually more broadly diffused among many disciplines.

\section{References}

Agogué, M., \& Kazakçi, A. (2014). 10 years of C-K theory: A survey on the academic and industrial impacts of a design theory. In A. Chakrabarti \& L. Blessing (Eds.), An anthology of theories and models of design. Philosophy, approaches and empirical explorations (pp. 219-235). Bangalore.

Agogué, M., Kazakçi, A., Hatchuel, A., Le Masson, P., Weil, B., Poirel, N., \& Cassotti, M. (2014). The impact of type of examples on originality: Explaining fixation and stimulation effects. Journal of Creative Behaviour, 48(1), 1-12.

Fayol, H. (1917). Administration Industrielle et Générale. Paris: Dunod et Pinat.

Fayol, H. (1918). Notice sur les travaux scientifiques et techniques de M. Henri fayol. Paris: Gauthier-Villars et Cie Editeurs. Online at the website of the French national library: http:// www.gallica.bnf.fr/(http://gallica.bnf.fr/ark:/12148/bpt6k904289.r=notice+fayol.langFR).

Hatchuel, A. (1994). Frédérick Taylor, une lecture épistémologique. L'expert, le théoricien et le doctrinaire. In J.-P. Bouilloud \& B.-P. Lécuyer (Eds.), L'invention de la gestion (pp. 53-64). Paris: L'Harmattan.

Hatchuel, A. (1995). Les marchés à prescripteurs. Crises de l'échange et genèse sociale. In A. Jacob \& H. Vérin (Eds.), L'inscription sociale du marché (pp. 205-225). Paris: L'Harmattan.

Hatchuel, A. (1996). Coordination and control international encyclopedia of business \& management. London: Thomson Business Press.

Hatchuel, A. (1997). Fondements des savoirs et légitimité des règles. In J.-P. Dupuy, B. Reynaud, \& P. Livet (Eds.), Les limites de la rationalité (Vol. 2, pp. 181-209). Paris: La Découverte.

Hatchuel, A. (1998). Organisations et marchá : la place des prescripteurs. Eléments d'une axiomatique de l'action collective. Condor Seminar, MINES ParisTech, Paris.

Hatchuel, A. (1999a). Connaissances, modèles d'interaction et rationalisations. Revue d'Économie Industrielle, 88, 187-209.

Hatchuel, A. (1999b). The Foucauldian Detour: A rebirth of organization theory? Human Relations, 52(4), 507-519. 
Hatchuel, A. (2001a). Quel horizon pour les sciences de gestion ? Vers une théorie de l'action collective. In A. David, A. Hatchuel, \& R. Laufer (Eds.), Les nouvelles fondations des sciences de gestion, éléments d'épistémologie en management. Paris: Vuibert.

Hatchuel, A. (2001b). Towards design theory and expandable rationality: The unfinished program of Herbert Simon. Journal of Management and Governance, 5(3-4), 260-273.

Hatchuel, A. (2001c). The two pillars of new management research. British Journal of Management, 12(Special Issue), 33-39.

Hatchuel, A. (2004). Histoire des révolutions de la gestion des entreprises. La Documentation française, Problèmes économiques, 2(852), 43-48.

Hatchuel, A. (2005). Towards an epistemology of collective action: Management research as a responsive and actionable discipline. European Management Review, 2, 36-47.

Hatchuel, A. (2006). Quelle analytique de la conception ? Parure et pointe en Design. In B. Flamand (Ed.), Le Design. Essais sur des théories et des pratiques. Paris: Institut Français de la Mode. Editions du Regard.

Hatchuel, A. (2007). Epistémologie de l'action et genèse des sciences sociales. L'expérience des sciences de gestion. In A.-C. Martinet (Ed.), Sciences du management. Epistémique, pragmatique et éthique. Paris: Vuibert.

Hatchuel, A. (2008). Du raisonnement de conception. Essai sur le "forcing" en théorie des ensembles. In A. Hatchuel \& B. Weil (Eds.), Les nouveaux régimes de conception (pp. 133-149). Paris: Vuibert.

Hatchuel, A. (2011). Paul Desjardins et les courants rationalisateurs. Autour de Auguste Detoeuf. In E. H. Sylvain Allemand, C. Paulhan (Eds.), De Pontigny à Cerisy: des lieux pour "penser avec ensemble." Paris, Hermann Editeurs.

Hatchuel, A. (2013). Deconstructing meaning: Industrial design as Adornment and Wit. Paper presented at the 10th European Academy of Design Conference, Gothenburg.

Hatchuel, A. (2016). Henri Fayol et la théorie du chef d'entreprise: une nouvelle figure de l'autorité au tournant du XXe siècle. Entreprises et Histoire, 2(83), 108-120.

Hatchuel, A., \& David, A. (2007). Collaborating for management research: from action research to intervention research in management. In A. B. Shani, S. A. Mohrman, W. A. Pasmore, B. A. Stymne, \& A. Niclas, (Eds.), Handbook of Collaborative Management Research. Thousands Oaks: Sage, 143-162.

Hatchuel, A., \& Molet, H. (1986). Rational modelling in understanding and aiding human decisionmaking: About two case-studies. European Journal of Operational Research, 24, 178-186.

Hatchuel, A., \& Ponssard, J.-P. (1996). Taylor et la théorie des incitations, quelques réflexions tirées de l'histoire économique: Cahier du Centre d'Econométrie de l'Ecole Polytechnique.

Hatchuel, A., \& Weil, B. (1995). Experts in organization, a knowledge-based perspective on organizational change (trans: L. Librecht.). Berlin: Walter de Gruyter.

Hatchuel, A., \& Weil, B. (1996). Entre individus et organisation, la dynamique des savoirs dans les transformations industrielles contemporaines. Educations, 13, pp. 56-63.

Hatchuel, A., \& Weil, B. (1999). Design-oriented Organizations: Toward a unified theory of design activities. Paper presented at the 6th International Product Development Management Conference (IPDM), EIASM, Cambridge, UK.

Hatchuel, A., \& Weil, B. (2002). C-K theory: Notions and applications of a unified design theory. Paper presented at the Herbert Simon International Conference on "Design Sciences".

Hatchuel, A., \& Weil, B. (2009). C-K design theory: An advanced formulation. Research in Engineering Design, 19, 181-192.

Hatchuel, A., Le Masson, P., \& Weil, B. (2001). From R\&D to R-I-D: Design strategies and the management of "innovation fields". EIASM, 8th international Product Development Management Conference. Enschede: University of Twente.

Hatchuel, A., Starkey, K., \& Pezet, E. (Eds.). (2005). Gouvernement, organisation et entreprise: l'héritage de Michel Foucault, Paris. 
Hatchuel, A., Weil, B., \& Le Masson, P. (2006). Building innovation capabilities: The development of design-oriented organizations. In J. T. Hage \& M. Meeus (Eds.), Innovation, science and industrial change, the handbook of research. Oxford, Oxford University Press.

Hatchuel, A., Weil, B., \& Le Masson, P. (2013). Towards an ontology of design: Lessons from C-K design theory and forcing. Research in Engineering Design, 24(2), 147-163.

Le Masson, P., Weil, B., Hatchuel, A., \& Cogez, P. (2012). Why aren't they locked in waiting games? Unlocking rules and the ecology of concepts in the semiconductor industry. Technology Analysis \& Strategic Management, 24(6), 617-630.

Levillain, K., Hatchuel, A., \& Segrestin, B. (2014). The blind spot of Corporate Social Responsibilities: Changing the legal framework of the firm. Paper presented at the EURAM, Valence.

Martinet, A.-C. (1990). Grandes questions épistémologiques et sciences de gestion. In A.-C. Martinet (Ed.), Epistémologies et sciences de gestion (pp. 9-29). Paris: Economica.

Moisdon, J.-C. (1984). Recherche en gestion et intervention. Revue Française de Gestion, (september-october) 61-73.

Segrestin, B., \& Hatchuel, A. (2011). Beyond agency theory, a post-crisis view of corporate law. British Journal of Management, 22, 484-499. doi:10.1111/j.1467-8551.2011.00763.x.

Segrestin, B., \& Hatchuel, A. (2012). Refonder l'entreprise. Paris: Le Seuil.

\section{Further Reading}

On the notion of "prescribing relationships", see: Hatchuel, 1995, 1998, 2000; Hatchuel \& Weil, 1996.

On C-K Theory, see: Elmquist \& Segrestin, 2007; Hatchuel, Le Masson, \& Weil, 2004; Hatchuel \& Weil, 2002, 2009; Kazakçi \& Tsoukias, 2005; Pascal Le Masson, Weil, \& Hatchuel, 2006.

On the theory of collective action and creative institutions, see: David \& Hatchuel, 2007; Hatchuel, 1994a, 1994c, 1996, 2001b, 2001c, 2004, 2005, 2008a, 2013; Hatchuel, Le Masson, \& Weil, 2005; Hatchuel, Starkey, Tempest, \& Le Masson, 2010; Hatchuel \& Weil, 2009; Hatchuel et al., 2006; Hatchuel et al., 2013; Pascal Le Masson, Hatchuel, \& Weil, 2010; Segrestin \& Hatchuel, 2011, 2012.

David, A., \& Hatchuel, A. (2007). From actionable knowledge to universal theory in management research. In R. A. B. Shani, S. A. Mohrman, W. A. Pasmore, B. Stymne, \& N. Adler (Eds.), Handbook of collaborative management. Thousands Oaks: Sage.

Elmquist, M., \& Segrestin, B. (2007). Towards a new logic for front-end management: From drug discovery to drug design in pharmaceutical companies. Creativity and Innovation Management Journal, 16(2), 106-120. doi:10.1111/j.1467-8691.2007.00424.

Hatchuel, A. (1994). Les savoirs de l'intervention en entreprise. Entreprises et Histoire, 7, 59-75.

Hatchuel, A. (2000). Rapport de prescription et conception collective du travail. Paper presented at the Journées de Bordeaux sur les pratiques de l'ergonomie, Bordeaux.

Hatchuel, A. (2008). Agency. In S. Clegg \& J. R. Bailey (Eds.), International encyclopedia of organization studies. Sage.

Hatchuel, A., \& Weil, B. (1996). La dynamique des savoirs dans les transformations industrielles contemporaines. Educations Permanentes, 13, 56-63.

Hatchuel, A., Le Masson, P., \& Weil, B. (2004). C-K theory in practice: Lessons from industrial applications. Paper presented at the The Design Society, Dubrovnik.

Hatchuel, A., Le Masson, P., \& Weil, B. (2005). The development of science-based products: Managing by design spaces. Creativity and Innovation Management Journal, 14(4), 345.

Hatchuel, A., Starkey, K., Tempest, S., \& Le Masson, P. (2010). Strategy as innovative design: An emerging perspective. Advances in Strategic Management, 27, 3-28.

Kazakçi, A. O., \& Tsoukias, A. (2005). The C-K design theory: A theoretical background for personal design assistants. Journal of Engineering Design, 16(4), 399-411. 
Le Masson P. (2001) De la R\&D à la RID: modélisation des fonctions de la conception et nouvelles organisations de la $R \& D$. Paris: Ecole des Mines de Paris.

Le Masson, P., Weil, B., \& Hatchuel, A. (2006). Les processus d'innovation. Conception innovante et croissance des entreprises. Paris: Hermès.

Le Masson, P., Hatchuel, A., \& Weil, B. (2010). Strategic management of innovation and design. Cambridge: Cambridge University Press. 